Vol. 3, No. 1, 2020

K. I. Kuznetsova, R. I. Fleychuk, A. D.Tolstenko, O. I. Hevus

Lviv Polytechnic National University,

Department of Organic Chemistry

Kateryna.I.Kuznetsova@1pnu.ua

\title{
SYNTHESIS OF PEROXIDE-CONTAINING HETERO-CHAIN AMPHIPHILIC OLIGOMERS AND THEIR COLLOID-CHEMICAL PROPERTIES
}

https://doi.org/

New surface-active oligomers were synthesized with the alternative placement of hydrophilic and lipophilic blocks based on substituted peroxide-containing oxetanes and polyesters of higher dicarboxylic acids and polyethylene glycols of different molecular weights. By acylation of peroxide-containing oxetane with dichloroanhydride decane and dodecanedioic acids, the corresponding bis (peroxyalkyloxetane) esters were synthesized. The interaction of the obtained diesters with polyethylene glycols PEG-300 and PEG-600 led to synthesys of amphiphilic oligomers, with reactive peroxide groups in the lateral branches of the macro-chain.

Key words: peroxide-containing amphiphilic oligomers, polyethylene glycols, oxetanes, dicarboxylic acids.

\section{Introduction}

Oligomers that contain alternatively placed hydrophilic and lipophilic blocks show amphiphilic properties. With a certain length of these blocks, they are able to respond to changes in the polarity of the medium, changing the size and conformation of the formed micellar structures [1-6]. The immobilization of such oligomers on various surfaces ensures their wetting with both organic non-polar solvents and water. Therefore, such surfaces are able to adapt to changes in the polarity of the medium. This ensures the stabilization of dispersions of micro- and nanoparticles with a modified surface in various media, including emulsions during phase inversion. Materials with such coatings (so-called "Janus coatings") are increasingly used in microelectronics, medicine, biotechnology [1-3], etc. Such oligomers are also capable of solubilizing lipophilic compounds insoluble in water, and hydrophilic water-soluble compounds in non-polar organic solvents [7]. This is extremely important for the creation of effective systems of targeted drug delivery, since many drug substances are insoluble in water and saline solution.

Among such amphiphilic oligomers, special attention is paid to polyesters of higher dicarboxylic acids and polyethylene glycols of different molecular weights. The availability of the starting compounds and the relative ease of preparation allows varying in a wide range of length ratios of hydrophilic and lipophilic fragments and, accordingly, the colloidchemical properties of the compounds. This allows the creation of surface-active oligomers with predicted colloid-chemical properties to solve specific scientific and technical problems [4-6].

Recently, considerable attention has been given to obtaining surface-active polymers of complex architecture, in particular comb-like polymers. One of the promising methods of obtaining these substances is copolymerization with the participation of macromers, grafting polymerization of monomers to the main macronutrient, which contains as initiating centers (peroxide, azo-, photoinitiative functions), as well as grafting oligomers to the terminal with oligomers with terminal substituents are reactive functional groups.

Amphiphilic oligomers of a number of polyester dicarboxylic acids and polyethylene glycols, which contain substituents in the main chain of the peroxide group, have not been described nowadays.

The presence of peroxide groups capable of initiating the grafting polymerization of monomers, macromers and oligomers will allow the production of amphiphilic branched copolymers whose main chain is capable of responding to changes in the 


\section{K. I. Kuznetsova, R. I. Fleychuk, A. D. Tolstenko, O.I. Hevus}

polarity of the medium. Such copolymers may be of interest when designing drug delivery systems, nanosensor materials, interfacial modifiers of colloidal systems, and the like [8].

To obtain polycondensation polymers of complex architecture, in particular dendromers, combs, etc. pentaerythritol and its derivatives, 2,2-di (hydroxymethyl) oxetane and spiro-bis-oxetane [911], are widely used as a reagent. The use of oxetanes allows the selective production of monoand di-derived pentaerythritol by hydroxyl groups. We have previously developed [12] a preparatively convenient method for the synthesis of new heterofunctional oxetans containing hydroxyl, peroxide, ester and other functions. Therefore, in our view, it was advisable to use these compounds to obtain functional amphiphilic oligomers.

\section{The aim of the study}

The purpose of this work is to develop a method for the synthesis of polyester higher dicarboxylic acids and polyethylene glycols containing peroxide groups as macro substituents of the macrochain.

\section{Results of the studies and their discussion} Synthesis of peroxide-containing oligomers with alternative placement of hydrophilic and lipophilic blocks.

Hydroxyalkyl substituted oxetanes are known to react under mild conditions with mono- and dicarboxylic acids or their chlorhydrides to preserve the oxetane cycle to form the corresponding oxetanecontaining esters [13-15]. Previously, we have also shown that functional oxetans are able to interact with polyethylene glycols of different molecular weights with the opening of the oxetane cycle and the formation of polyethers [12]. When used in these reactions peroxide-containing oxetanes peroxide group is saved [15].

Therefore, as a substrate for the production of amphiphilic oligomers containing alkyl peroxide substituents of the macro-chain, peroxide-containing oxetane (1), synthesized by us previously, was used [16]. Peroxide-containing oligomers were obtained in two steps. On the first of these, the corresponding bis (peroxyalkyloxetane) diesters $(2 a, b)$ were synthesized by acylation of peroxide-containing oxetane (1) by the hydroxyl group of higher dicarboxylic acids (sebacic, dodecanedioic) (2a, b) (Fig. 1).

The reaction was carried out at a molar ratio of hydroxyoxetane - dicarboxylic acid as $2: 1$ at a temperature of $0-5{ }^{\circ} \mathrm{C}$ in tetrahydrofuran. Triethylamine was used as the hydrogen chloride acceptor. The yield of peroxide-containing bis-oxetanes $(2 a, b)$ was $80-86 \%$. It should be noted that when using other methods for the synthesis of oxetanecontaining esters (esterification or transesterification of diesters of dicarboxylic acids) there is a partial breakdown of the oxetane cycle by carboxyl groups, as well as polymerization of peroxide-containing oxetane (1) with the participation of hydroxyl group. In addition, under the conditions of esterification observed partial heterolysis of peroxide groups.

In the second stage, in order to obtain the target amphiphilic peroxide-containing heterochain oligoesters (3a-c), the interaction of the synthesized bis (alkylperoxyoxetane) esters (2a, b) with PEG-300 and PEG-600 polyethylene glycols with mass / mass of $600 \mathrm{~mol}$ (Fig. 2).

The first attempts to attach polyethylene glycol (PEG) to oxetanes using as the catalyst basic aluminum oxide, which was successfully used in the reaction of oxetane with tert-butylhydroperoxide (TBGP), failed. At the reaction temperature up to $100{ }^{\circ} \mathrm{C}$, no addition occurred, at higher temperature the destruction of the peroxide group and the formation of resinous products of an undetermined structure were observed. When used as a catalyst, zinc chloride interaction also did not occur.PEG coupling was only possible when used as a BF3 • OEt 2 catalyst and the reaction was carried out in anhydrous dichloromethane.
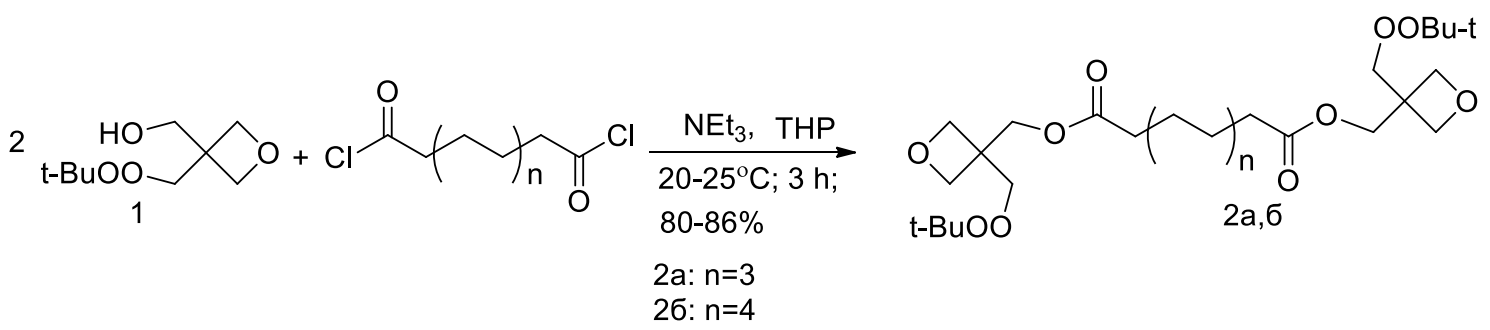

Fig. 1. Scheme of preparation of bis (peroxyoxetane) 


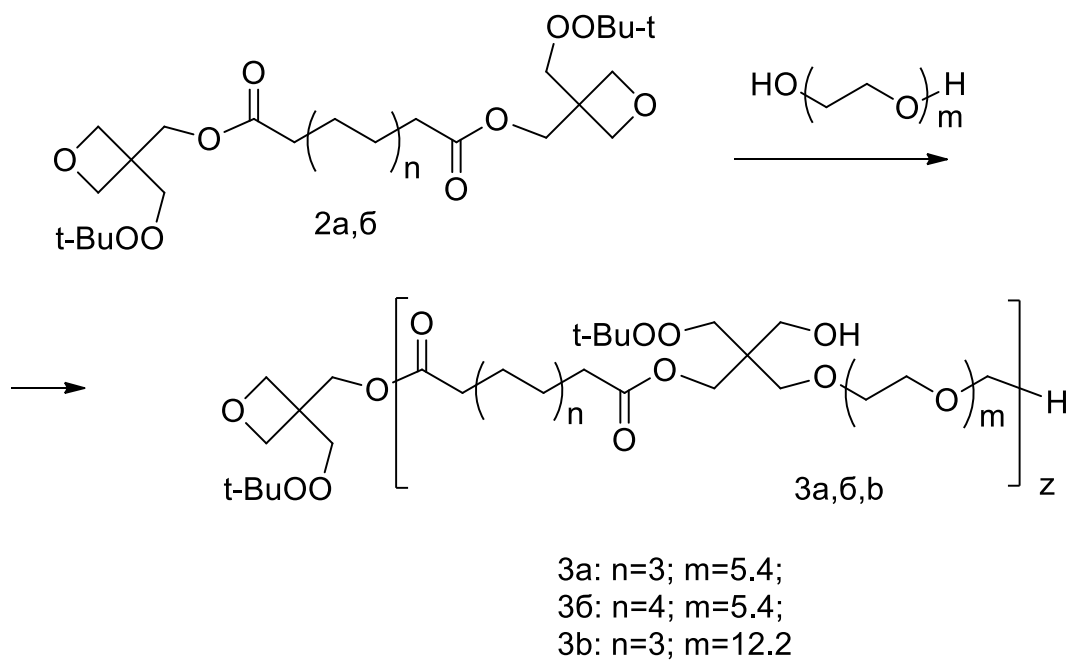

Fig. 2. Scheme of obtaining alternatic peroxide-containing oligomers

For this purpose, the oxetane complex with Boron fluoride was prepared, which was obtained at a temperature not higher than $-10{ }^{\circ} \mathrm{C}$ by the addition of Boron fluoride etherate to a solution of $10 \%$ bis (peroxyoxetane) solution $(2 \mathrm{a}, \mathrm{b})$ in dichloromethane.The resulting complex with the catalyst under vigorous stirring was added to anhydrous polyethylene glycol (dioxetane-polyethylene glycol ratio, 1: 1.1) and the reaction mixture was maintained at $38-42{ }^{\circ} \mathrm{C}$ for $15 \mathrm{~h}$. The reaction gave the desired product in a yield of 63-68\%. By-products of the reaction were spatially crosslinked polymers in an amount up to $10 \%$, which were easily removed from the reaction mixture by centrifugation. In the process of synthesis there were some problems with the analytical control of the course of this reaction and the determination of the molecular weight of the reaction product. This is due to the fact that the number of functional groups (free $\mathrm{OH}$ groups) with increasing conversion of reagents does not change. $\mathrm{OH}$ groups are present both in the original polyethylene glycol and are formed as a result of its attachment to oxetane. The characteristic viscosity of oligomer solutions due to the peculiarity of their behavior in the solutions also makes it impossible to determine their molecular weight. To determine the molecular weight of the oligomers, it is proposed to use the ratio of the integral intensities of the $\mathrm{CH} 2 \mathrm{OH}$ group methylene proton (doublet) signals with a chemical shift of $3.89 \mathrm{ppm}$ formed as a result of the breaking of the oxetane cycle and protons of the $\alpha$ methylene groups (triplet) of ester of dicarboxylic acid $\mathrm{CH} 2 \mathrm{C}(\mathrm{O}) \mathrm{O}$ with chemical shift of $2.27 \mathrm{ppm}$, whose position on the $1 \mathrm{H}$ NMR spectrum is practi- cally unchanged. It was found that the average molecular weight $\mathrm{Mw}$ of oligomers was 7530-9740 and after reaching this value, with a further increase in the time of the interaction practically did not change.

The colloid-chemical properties of alternate peroxide-containing oligomers

An important feature of the synthesized macroinitiators $(3 a-c)$ is that they are all high molecular weight substances. Like other polymers containing hydrophilic and hydrophobic blocks, they exhibit surface-active properties. As the concentration of macroinitiators (3a-c) increases, the surface tension of their aqueous solutions decreases and becomes almost constant above a certain value, which obviously corresponds to the critical micelle formation concentration.

As can be seen from the data in Table. 1, the CCM values of macroinitiators $3 \mathrm{a}, \mathrm{b}$ containing PEG-300 units are significantly lower than compound $3 \mathrm{c}$ with PEG-600 fragments. This is due to the increase in the hydrophilic component in the initiator $3 \mathrm{c}$, which consists of longer polyethylene glycol chains.

Macromolecules of surface-active initiators (3a-c) containing alternatively placed hydrophilic polyethylene glycol units with high segmental motility and sufficiently long lipophilic residues of aliphatic higher dicarboxylic acids and tertbutylhydroperoxidate respond to the changing nature of the environment. This is evidenced by the ability to wet both hydrophilic and lipophilic surfaces (glass and polystyrene). 
Critical concentration of micelle formation, surface tension, and characteristic viscosity of amphiphilic macroinitiators with alternative hydrophilic and hydrophobic blocks

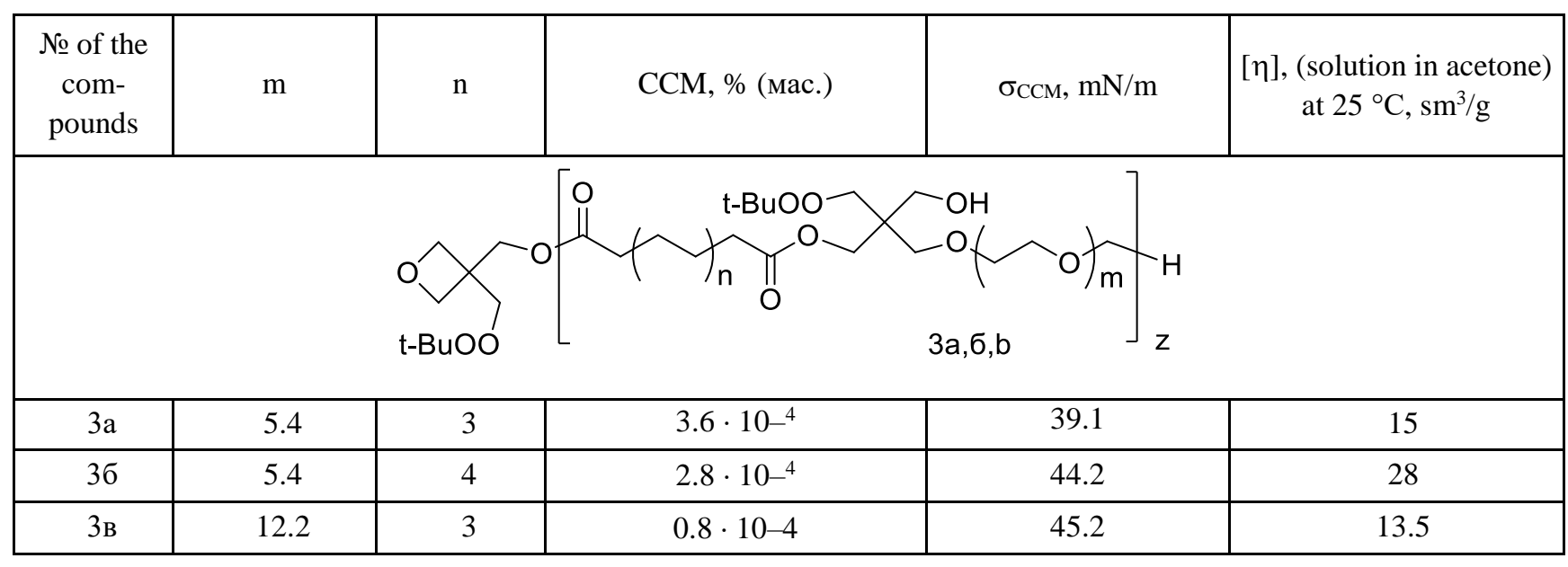

Such properties of the colloid-chemical behavior of the synthesized macroinitiators make it possible to predict the possibility of their use to create thin inversion-capable films on various substrates.

\section{Materials and methods of research}

Solvents (tetrahydrofuran, dichloromethane, dioxane) used "puriss." qualifications, distilled immediately before use. Triethylamine used qualifications "puriss."

The identity of the synthesized compounds was checked by thin layer chromatography on Silica gel 60 F254 (Merck) plates in a cuvette, running through the solvent front of $100 \mathrm{~mm} .1 \mathrm{H} \mathrm{NMR}$ spectra were recorded on the "Brucker 150" device with a working frequency of $300 \mathrm{MHz}$ in deuterochloroform at a concentration of substances of $5 \ldots 10 \%$, and the internal standard is hexamethyldisiloxane. The purity of synthesized compounds (volatiles) was controlled by gas-liquid chromatography on a Selmichrom-1 chromatograph; column with a length of $1 \mathrm{~m}$ and a diameter of $3 \mathrm{~mm}$, a carrier "Chromaton N-super" (granularity 0,12 ... $0,16 \mathrm{~mm}$ ); liquid phase silicone elastomer SE-30 or Carbowax 40 M (5 \% mass); detector - cathometer; gas carrier - helium. Gas-carrier consumption - 2 1/h.Temperature of evaporatoris $200{ }^{\circ} \mathrm{C}$, programming the column temperature from 150 to $200{ }^{\circ} \mathrm{C}$ at a speed of $7{ }^{\circ} \mathrm{C} / \mathrm{min}$.

The content of active oxygen in hydroperoxides was determined iodometrically in acetic acid solution by the method.The surface tension of the solutions of the obtained surfactant at a temperature of $20^{\circ} \mathrm{C}$ was determined by method of DuNui using a platinum ring.

\section{3-[(tert-butylperoxy)methyl]oxetane-3-}

yl\}methanol (1) obtained by the interaction of 0.135 $\mathrm{g}(0.0075 \mathrm{~mol})$ of 3-bromomethyl-3-hydroxymethyloxetane and $0.202 \mathrm{~g}(0.0025 \mathrm{~mol})$ of TBHP in the presence of $2.0 \mathrm{~g}$ of aluminum oxide and $9.0 \mathrm{ml}$ of tetrahydrofuran in argon atmosphere by the method [15]. Received $0.64 \mathrm{~g}$ (yield $45 \%$ ), which had the following characteristics: m.p. $16.0-17.5{ }^{\circ} \mathrm{C}$. Molecular weight: Calculated 201.5. Found, \%: C 56.88; $\mathrm{H}, 9.51 . \mathrm{C}_{9} \mathrm{H}_{18} \mathrm{O}_{4}$. Calculated, \%: $\mathrm{C} 56.82 ; \mathrm{H}$, 9.54. ${ }^{1} \mathrm{H}$ NMR $(\mathrm{CDCl} 3), \delta, \mathrm{ppm}: 1.24(\mathrm{~s}, 9 \mathrm{H}$, $\left.\mathrm{C}\left(\mathrm{CH}_{3}\right)_{3}\right), 2.88(\mathrm{t}, \mathrm{J}=5,3 \mathrm{~Hz}, 1 \mathrm{H},-\mathrm{O} \underline{\mathrm{H}}), 3.89$ $\left(\mathrm{d}, \mathrm{J}=5,4 \mathrm{~Hz}, 2 \mathrm{H},-\underline{\mathrm{C}}_{2}-\mathrm{OH}\right), 4.28\left(\mathrm{~s}, 2 \mathrm{H}, \mathrm{C}_{2}-\right.$ $\left.\mathrm{OOC}\left(\mathrm{CH}_{3}\right)_{3}\right), 4.31,4.45$ (ABquartet, $\mathrm{J}=5.8 \mathrm{~Hz}, 4 \mathrm{H}$, $\mathrm{CH}_{2} \mathrm{O}$, oxetanering).

Peroxy-containingbis-oxetane(2a). To a solution of $2.67 \mathrm{~g}(0.01 \mathrm{~mol})$ of $3-$ [(tert-butyl peroxy) methyl] oxetan-3-yl\} methanol (1) and $1.11 \mathrm{~g}(0.011 \mathrm{~mol})$ of triethylamine in $15 \mathrm{ml}$ of tetrahydrofuran at $0-5^{\circ} \mathrm{C}$ and $2.39 \mathrm{~g}(0.01 \mathrm{~mol})$ of octandicarboxylic acid dichloroanhydride were added dropwise to effective stirring. The mixture was kept at the indicated temperature and stirred for 3 hours, brought the reaction mixture to room temperature and stirred for another 2 hours. The precipitate was filtered off, the residue was chromatographed on alumina. After distillation of 
the solvent, $4.4 \mathrm{~g}(80 \%)$ of the title compound were obtained. Molecular weight 540 calculated 546.69. Found, \%: $\quad$ C $\quad 61.50 \quad \mathrm{H} \quad 9.18 . \quad \mathrm{C}_{28} \mathrm{H}_{50} \mathrm{O}_{10}$. Calculated, \%: C 61,52; H 9,22. ${ }^{1} \mathrm{H}$ NMR (CDCl3), $\delta$, ppm: 1,20 (c, $\left.18 \mathrm{H}, \mathrm{C}\left(\mathrm{CH}_{3}\right)_{3}\right) ; 1,22-1,43(\mathrm{M}, 8 \mathrm{H}$, $\left.\left(\mathrm{CH}_{2}\right)_{4}\right) ; 1,61$ (м, $J=7.1 \mathrm{~Hz}, 4 \mathrm{H}, \mathrm{C}_{2} \mathrm{CH}_{2} \mathrm{C}(\mathrm{O})$ ); $2,27 \mathrm{t}\left(4 \mathrm{H}, \mathrm{CH}_{2} \mathrm{C}(\mathrm{O}) \mathrm{O}\right) ; 4,15\left(\mathrm{~s}, 4 \mathrm{H}, \mathrm{CH}_{2}-\mathrm{O}\right.$, oxetanechain); 4.26 (s, $4 \mathrm{H}, \mathrm{C}_{2}-\mathrm{OOBu}-\mathrm{t}$ ); 4.30, 4.43 (ABquartet, $\mathrm{J}=5.7 \mathrm{~Hz}, 8 \mathrm{H}, \mathrm{CH}_{2} \mathrm{O}$, oxetanering).

Peroxide-containing bis-oxetane (2b). Prepared analogously to the synthesis of compound (2a) of $2.67 \mathrm{~g}(0.01 \mathrm{~mol})$ of $3-$ [(tert-butyl peroxy) methyl] oxetan-3-yl $\}$ methanol (1) and $2.67 \mathrm{~g}(0.01 \mathrm{~mol})$ dodecandicarboxylic acid dichlorohydride. After isolation, $4.8 \mathrm{~g}(86 \%)$ of the title compound were obtained. Molecular weight562 calculated 556.77. Found, \%: C 62.08; H, 9.30. $\mathrm{C}_{29} \mathrm{H}_{52} \mathrm{O}_{10}$. Calculated, $\%$ : C 62,12; $\mathrm{H} 9,35 .{ }^{1} \mathrm{H}$ NMR $\left(\mathrm{CDCl}_{3}\right), \delta$, ppm: 1,21 (c, $\left.18 \mathrm{H}, \mathrm{C}\left(\mathrm{CH}_{3}\right)_{3}\right) ; 1,20-1,43$ (м, $\left.10 \mathrm{H},\left(\mathrm{CH}_{2}\right)_{4}\right) ; 1,63$ (м, $\left.J=7.1 \mathrm{~Hz}, 4 \mathrm{H}, \mathrm{CH}_{2} \mathrm{CH}_{2} \mathrm{C}(\mathrm{O})\right) ; 2,27 \mathrm{t}(4 \mathrm{H}$, $\left.\mathrm{CH}_{2} \mathrm{C}(\mathrm{O}) \mathrm{O}\right) ; 4,15$ (s, 4H, $\mathrm{CH}_{2}-\mathrm{O}$, oxetanechain); 4.26 (s, 4H, $\underline{\mathrm{H}}_{2}-\mathrm{OOBu}-\mathrm{t}$ ); 4.30, 4.43 (ABquartet, $\mathrm{J}=5.7 \mathrm{~Hz}, 8 \mathrm{H}, \mathrm{CH}_{2} \mathrm{O}$, oxetanering).

Peroxide-containing macroinitiator (3a). To a solution of $3.30 \mathrm{~g}(0.011 \mathrm{~mol})$ of PEG-300 in $10 \mathrm{ml}$ of dichloromethane with vigorous stirring was carefully added dropwise a complex of catalyst $\mathrm{BF} 3 \cdot \mathrm{OEt} 2$ with a solution of $5.46 \mathrm{~g}(0.01 \mathrm{~mol})$ of bis (peroxyoxetane) (2a). The mixture was stirred at 38$42{ }^{\circ} \mathrm{C}$ for 15 hours. Then centrifugation separated the sewn fraction, neutralized boron fluoride by adding a saturated solution of sodium bicarbonate and separated by centrifugation the aqueous phase. In the vacuum of the water jet pump, the solvent was distilled off, the residue was kept at a residual pressure of $0.1 \mathrm{~mm} \mathrm{Hg}$ for 2 hours. Obtained $7.79 \mathrm{~g}$ (yield $89 \%$ ). Calculated, \%: C 57.66; H $9.23 \mathrm{O}_{\text {act }}$ 0.70. Found, \%: C 57.72; H 9.29; $\mathrm{O}_{\text {act. }}$ 0,60; $\mathrm{M}_{\mathrm{w}} 7530 \mathrm{~g} /$ moles. [ $\left.\eta\right] 15 \mathrm{sm}^{3} / \mathrm{g} .{ }^{1} \mathrm{H}$ NMR $\left(\mathrm{CDCl}_{3}\right), \delta$, ppm: 1,21 (с, $\left.18 \mathrm{H}, \mathrm{C}\left(\mathrm{CH}_{3}\right)_{3}\right) ; 1,20-1.43$ (м, $10 \mathrm{H}$, $\left.\left(\mathrm{CH}_{2}\right)_{4}\right) ; 1,63$ (м, $J=7.1 \mathrm{~Hz}, 4 \mathrm{H}, \mathrm{CH}_{2} \mathrm{CH}_{2} \mathrm{C}(\mathrm{O})$ ); 2,27 t $\left(4 \mathrm{H}, \mathrm{CH}_{2} \mathrm{C}(\mathrm{O}) \mathrm{O}\right) ; 3.42-2,44$ (s, 27H, PEG backbone); 3.75 (s, $\left.1 \mathrm{H}, \mathrm{CH}_{2} \mathrm{O} \underline{\mathrm{H}}\right) ; 3.89\left(\mathrm{~s}, 4 \mathrm{H}, \mathrm{C}_{2}-\right.$ $\mathrm{OH}) ; 4.26$ (s, 4H, $\left.\mathrm{C}_{2}-\mathrm{OOBu}-\mathrm{t}\right)$.

\section{The peroxide-containing macroinitiator} (3b) was prepared analogously to compound (3a) from a solution of $3.30 \mathrm{~g}(0.011 \mathrm{~mol})$ of PEG-300 in $10 \mathrm{ml}$ of dichloromethane and a BF3 - OEt2 catalyst complex with a solution of $5.62 \mathrm{~g}(0.01 \mathrm{~mol})$ of bis (peroxyoxetane). (2b). Received $7.40 \mathrm{~g}$ (yield $83 \%$ ) of the target macroinitiator. Calculated, \%: C 58.11; $\mathrm{H}, 9.31$. Oact. 0.75; Found, \%: C 58.20; H 9,27. Oact.

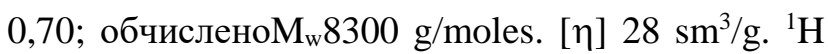
NMR $\left(\mathrm{CDCl}_{3}\right), \delta$, ppm: 1,21 (c, $\left.18 \mathrm{H}, \mathrm{C}\left(\mathrm{CH}_{3}\right)_{3}\right)$; 1,20-1,43 (м, $\left.10 \mathrm{H},\left(\mathrm{CH}_{2}\right)_{4}\right) ; 1,63$ (м, $J=7.1 \mathrm{~Hz}, 4 \mathrm{H}$, $\left.\mathrm{CH}_{2} \mathrm{CH}_{2} \mathrm{C}(\mathrm{O})\right) ; 2,27 \mathrm{t}\left(4 \mathrm{H}, \mathrm{CH}_{2} \mathrm{C}(\mathrm{O}) \mathrm{O}\right) ; 3.42-2,44$ (s, 27H, PEG backbone); 3.75 (s, $1 \mathrm{H}, \mathrm{CH}_{2} \mathrm{OH}$ ); 3.90 (s, $\left.4 \mathrm{H}, \mathrm{C}_{2}-\mathrm{OH}\right) ; 4,10$ (s, 4H, $\left.\underline{\mathrm{C}}_{2}-\mathrm{OH}\right) ; 4.26(\mathrm{~s}, 4 \mathrm{H}$, $\left.\mathrm{CH}_{2}-\mathrm{OOBu}-\mathrm{t}\right)$.

The peroxide-containing macroinitiator $(3 \mathrm{c})$ was prepared analogously to compound (3a) from a solution of $6.60 \mathrm{~g}(0.011 \mathrm{~mol})$ of PEG-600 in $10 \mathrm{ml}$ of dichloromethane and the BF3 - OEt2 catalyst complex with a solution of $5.4 \mathrm{~g}(0.01 \mathrm{~mol})$ of bis (peroxyoxetane) (2a). Received $10.32 \mathrm{~g}$ (yield $86 \%$ ) of the target macroinitiator. Calculated, \%: C 56.78; $\mathrm{H} \mathrm{9,21.} \mathrm{O}_{\text {act. }}$ 1.72; Found \%: C 56.81; H 9,18. $\mathrm{O}_{\text {act. }}$. 1.6; $\mathrm{M}_{\mathrm{w}} 9740 \mathrm{~g} /$ moles. [ $\left.\eta\right] 13.5 \mathrm{sm}^{3} / \mathrm{g} .{ }^{1} \mathrm{H} \mathrm{NMR}$ $\left(\mathrm{CDCl}_{3}\right), \delta$, м. ч.: $1,21\left(\mathrm{c}, 18 \mathrm{H}, \mathrm{C}\left(\mathrm{CH}_{3}\right)_{3}\right) ; 1,20-1,43$ (м, $\left.8 \mathrm{H},\left(\mathrm{CH}_{2}\right)_{4}\right) ; 1,63($ м, $J=7.1 \mathrm{~Hz}, 4 \mathrm{H}$, $\left.\mathrm{CH}_{2} \mathrm{CH}_{2} \mathrm{C}(\mathrm{O})\right) ; 2,27 \mathrm{t}\left(4 \mathrm{H}, \mathrm{CH}_{2} \mathrm{C}(\mathrm{O}) \mathrm{O}\right) ; 3.42-3.44$ (m, $\approx 29 \mathrm{H}$, PEGchain); $3.75\left(\mathrm{~s}, 1 \mathrm{H}, \mathrm{CH}_{2} \mathrm{OH}\right) ; 3,87$ (s, $\left.4 \mathrm{H}, \mathrm{C}_{2}-\mathrm{OH}\right) ; 4.26$ (s, 4H, $\left.\mathrm{CH}_{2}-\mathrm{OOBu}-\mathrm{t}\right)$.

\section{Conclusions}

The interaction of dicarboxylic acid diesters and substituted peroxide-containing oxetanes with polyethylene glycols of different lengths yielded new amphiphilic oligomers containing reactive peroxide groups as substituents near the main chain. The realization of the reactivity of these centers in the reactions of grafting polymerization or polymer-like transformations will make it possible to obtain graft copolymers of the brush structure to create new types of drug carriers based on them.

\section{References}

1. Gesang, T., Höper, R., Possart, W., Petermann, J., Hennemann, O.-D. (1996). AFM studies of the initial stages of spin-coated prepolymer film growth on silicon wafers. Advanced Materials, 8(10), 829-833. doi:10.1002/adma.19960081014.

2. Luo, Q., Chen, X., Liu, Z., Sun, Z., Ming, N. (1997). Deposition of oriented polymer films for liquid crystal slignment by pulsed laser ablation. Applied Surface Science, 108(1), 89-93. doi:10.1016/s01694332(96)00545-4.

3. Park, M., Harrison, C., Chaikin P.M., (1997) Block copolymer lithography: Periodic arrays of $\sim 10$ to the 11 th 
power holes in 1 square centimeter. Science. 276 (5317). 1401-1404.

4. Schmolka, I.R. (1977). A review of block polymer surfactants. Journal of the American Oil Chemists' Society. 54. 110.

5. Alexandridis, P., Hatton, T.A (1995). Poly(ethylene oxide)-poly(propylene oxide)-poly (ethylene oxide) block copolymer surfactants in aqueous solutions and at interfaces: thermodynamics, structure, dynamics, and modeling. Colloids and Surfaces A: Physicochemical and Engineering Aspects. 96(1-2), 1-46. doi:10.1016/0927-7757(94)03028-X

6. Voronov A., Vasylyev S., Kohut A., Peukert, W. (2008). Surface activity of new invertible amphiphilic polyesters based on poly(ethylene glycol) and aliphatic dicarboxylic acids. Journal of Colloid and Interface Science, 323(2), 379-385. doi:10.1016/j.jcis.2008.04.053

7. Voronov, A., Kohut, A., Peukert, W., Voronov, S., Gevus, O., Tokarev, V. (2006). Invertible Architectures from Amphiphilic Polyesters. Langmuir, 22(5), 19461948. doi:10.1021/la052225z.

8. Bahatofunktsionalni nanomaterialy dlia biolohii $\mathrm{i}$ medytsyny: molekuliarnyi dyzain, syntez i zastosuvannia (za redaktsiyeyu ch.-korespondenta NAN Ukrainy R. S. Stoika). [Multifunctional nanomaterials for biology and medicine: molecular design, synthesis and application]. (Edited by R. S. Stoika, corresponding Member of NAS of Ukraine), Kyiv, Naukova dumka. 2017. 363 p. (in Ukrainian).

9. Nishikubo, T., Kameyama, A., Kudo, H. (2006). Synthesis of Polymers with Well-defined Structures by Novel Ring-opening Reactions of Oxetanes. Journal of Synthetic Organic Chemistry, Japan, 64(9), 934-946. doi:10.5059/yukigoseikyokaishi.64.934
10. Kudo, H., Nishikubo, T. (2007). Catalytic reactions of oxetanes with protonic reagents and aprotic reagents leading to novel polymers. Journal of Polymer Science Part A: Polymer Chemistry, 45(5), 709-726. doi:10.1002/pola.21828

11. Semlitsch, S., Torron, S., Johansson, M., Martinelle, M. (2016). Enzymatic catalysis as a versatile tool for the synthesis of multifunctional, bio-based oligoester resins. Green Chemistry, 18(7), 1923-1929. doi: $10.1039 / \mathrm{c} 5 \mathrm{gc} 02597 \mathrm{~d}$

12. Kuznetsova K. I., Vostres V. B., Fleychuk R. I., Hevus O. I., "Synthesis of surface-active monomers and peroxides on a disubstituted oxetane basis". Voprosy khimii i khimicheskoi tekhnologii, 2019, No. 2, pp. 5-11. http://dx.doi.org/10.32434/0321-40952019-123-2-5-11

13. Nishikubo, T., \& Kudo, H. (2007). High Performance Photo-curable Polymers and Oligomers Based on Novel Ring-opening Reactions of Oxetanes. MRS Proceedings, 1005. doi:10.1557/proc-1005-q02-04.

14. Bobrova K. I., Fleychuk R. I., Hevus O. I. "SyntezneyonohennykhPARnaosnovidyzamishchenykhok setaniv". Visnyk Natsional'noho universytetu 'L'vivs'ka politekhnika" Khimiya, tekhnolohiya rechovyn ta yikh zastosuvannya, 2017, No. 868, P. 3-8.

15. Bobrova K. I., Fleychuk R. I., Hevus O. I. Decomposition of three-, four-, and five-membered oxygenheterocyclesbytert-butylhydroperoxide // Bulletin of the Lviv Polytechnic National University. No. 886. 2018. - C. 52-58.

16. Toroptseva A. M., Belogorodskaya K. V., Bondarenko V. M. Laboratornyy praktikum po khimii i tekhnologii vysokomolekulyarnykh soyedineniy. - L.: Khimiya, 1972. - 416 p.

\section{К. І. Кузнецова, Р. І. Флейчук, А. Д. Толстенко, О. І. Гевусь Національний університет “Львівська політехніка”, кафедра органічної хімії \\ Kateryna.I.Kuznetsova@lpnu.ua}

\section{СИНТЕЗ ПЕРОКСИДОВМІСНИХ ГЕТЕРОЛАНЦЮГОВИХ АМФІФІЛЬНИХ ОЛІГОМЕРІВ ТА ЇХ КОЛОЇДНО-ХІМІЧНІ ВЛАСТИВОСТІ}

Синтезовано нові поверхнево-активні олігомери 3 альтернатним розміщенням гідрофільних та ліпофільних блоків на основі заміщених пероксидовмісних оксетанів та поліестерів вищих дикарбонових кислот і поліетиленгліколів різної молекулярної маси. Ацилюванням пероксидовмісного оксетану дихлорангідридами декан- та додекандіової кислот синтезовано відповідні біс(пероксиалкілоксетан)естери. Взаємодією отриманих діестерів 3 поліетиленгліколями PEG-300 та PEG-600 синтезовано амфіфільні олігомери, 3 реакційноздатними пероксидними групами в бічних відгалуженнях макроланцюга.

Ключові слова: пероксидовмісні амфіфільні олігомери, поліетиленгліколі, оксетани, дикарбонові кислоти. 